New Deal Activity and the States, 1933 to 1939

Don C. Reading

The Journal of Economic History, Vol. 33, No. 4. (Dec., 1973), pp. 792-810.

Stable URL:

http://links.jstor.org/sici?sici=0022-0507\%28197312\%2933\%3A4\%3C792\%3ANDAATS\%3E2.0.CO\%3B2-O

The Journal of Economic History is currently published by Economic History Association.

Your use of the JSTOR archive indicates your acceptance of JSTOR's Terms and Conditions of Use, available at

http://www.jstor.org/about/terms.html. JSTOR's Terms and Conditions of Use provides, in part, that unless you have obtained prior permission, you may not download an entire issue of a journal or multiple copies of articles, and you may use content in the JSTOR archive only for your personal, non-commercial use.

Please contact the publisher regarding any further use of this work. Publisher contact information may be obtained at http://www.jstor.org/journals/eha.html.

Each copy of any part of a JSTOR transmission must contain the same copyright notice that appears on the screen or printed page of such transmission.

JSTOR is an independent not-for-profit organization dedicated to and preserving a digital archive of scholarly journals. For more information regarding JSTOR, please contact support@jstor.org. 


\section{New Deal Activity and the States, 1933 to 1939}

$T^{N}$ the three months after his inauguration-the now famous 100 days-Franklin Roosevelt proposed a veritable barrage of programs that were passed by Congress-programs which were to have a profound effect on the American economy. From this beginning sprang forth the economic policy of the 1930's which was aimed at returning the nation to prosperity and changing its social and economic structure. The programs were directed toward specific as well as general problems and affected differently the various geographic areas of the nation.

Comparative studies of federal expenditure programs in the various states are limited, especially before World War II, by incomplete or nonexistent data. A set of mimeographed reports recently brought to light makes possible such studies for the $1933-1939$ period. ${ }^{1}$ Prepared by the Office of Government Reports, Statistical Section, for Franklin Roosevelt's 1940 campaign, this set of forty-eight reports details each New Deal program year by year for the period 19331939. The reports also contain material on the organization of various programs and outline work accomplishments in each state. For statistical and analytical purposes the reports are an invaluable set of compatible data for comparing federal activity in various states during the 1933 to 1939 period. All data in the statistical analysis which follows, unless otherwise cited, have been taken from these reports. The one major exception is the expenditures of the Tennessee Valley Authority, which are not reported in the set referred to, but which have been ascertained and included in this study. ${ }^{2}$

I wish to thank Evan B. Murray, Gary B. Hansen, and Reed R. Durtschi for their helpful suggestions and criticisms. A special thanks goes to Leonard J. Arrington whose guidance was invaluable and James B. McDonald for direction in statistical problems. I also benefitted from the suggestions of the anonymous referees and the editor. Much of this paper is drawn from an unpublished Ph.D. dissertation, Utah State University, 1972.

1 Office of Government Reports, Statistical Section, Report No. 10, Volume II, Washington, D.C., 1940, mimeographed. Copy in the library of the Superintendent of Documents, Washington, D.C.; Xerox copy in Utah State University Library, Logan, Utah.

2 Frank F. Smith, Letter to Mr. Bobby M. Corcoran, November 4, 1970. (Mr. Smith is Director of the Tennessee Valley Authority, Knoxville, Tennessee.) 
The following study does not attempt to differentiate between types of programs. Some New Deal Programs were established to meet a specific emergency; others were directed toward aiding depressed areas for the duration of the depression; still others were permanent and lasting. Some programs were the creation of New Deal planners; others were holdovers from the previous administrations. The Roosevelt Administration viewed many well-established programs (the Bureau of Public Roads, the Veterans' Administration, the Bureau of Reclamation) as vehicles for further "pump-priming" and methods of increasing employment.

These are certain problems in attempting to separate New Deal allocations by states. Many projects had a multi-state impact. Dams constructed in one state would influence employment greatly in states close to the construction site. CCC camps attracted workers from all states and $\$ 25.00$ of the $\$ 30.00$ received each month was sent home to needy dependents. As an example, in Idaho in August of 1939 , only 1,127 of the state's 9,655 CCC camp members claimed Idaho as their state of residence. The benefits of many projects such as flood control, regional power networks, and soil conservation would accrue to states which did not receive the allocation for the project. While these problems are troublesome, there seems no rational method for compensation which would not add greater confusion. Therefore all program allocations to a given state were assumed to affect that state.

A general and significant pattern emerges from this state-by-state, region-by-region analysis of New Deal programs. The western states, and to a greater extent the mountain states, received a much larger per capita share of New Deal loans and expenditures than other regions of the country. The south, which Franklin Roosevelt proclaimed as the "Nation's Number One Economic Problem" received, on a per capita basis, the smallest allocations from nearly all programs.

Many programs, when analyzed in relation to the states or regions which received the largest or smallest allocations on both an absolute and a per capita basis, yield results that are not particularly surprising. For example, the largest expenditures from the Agricultural Adjustment Administration (both the 1933 and 1938 acts) flowed to the southern and plains states; that is, the states with the highest percentages of the economy engaged in farming. The lowest amount went to the northeastern states, with a relatively low percent 
TABLE 1

NEW DEAL EXPENDITURES, LOANS, AND INSURANCE BY STATES, 1933 TO 1939

Absolute Allocation 1933-1939

\begin{tabular}{|c|c|c|c|c|c|}
\hline & & & & & \\
\hline State & Rank & $\begin{array}{l}\text { Amount } \\
\text { in } \\
\text { Dollars }\end{array}$ & State & Rank & $\begin{array}{l}\text { Amount } \\
\text { in } \\
\text { Dollars }\end{array}$ \\
\hline New York & 1 & 4214632166 & Nevada & 1 & 1499.39 \\
\hline California & 2 & 3054808597 & Montana & 2 & 986.30 \\
\hline Illinois & 3 & 2784416009 & Wyoming & $\overline{3}$ & 896.91 \\
\hline Ohio & 4 & 2548119820 & Arizona & 4 & 791.46 \\
\hline Pennsylvania & 5 & 2512598632 & Idaho & 5 & 744.15 \\
\hline Texas & 6 & 2106916828 & North Dakota & 6 & 707.84 \\
\hline Michigan & 7 & 1883495906 & South Dakota & 7 & 701.61 \\
\hline New Jersey & 8 & 1335440333 & New Mexico & 8 & 689.76 \\
\hline Missouri & 9 & 1234146757 & Utah & 9 & 569.49 \\
\hline Massachusetts & 10 & 1216327872 & California & 10 & 538.10 \\
\hline Iowa & 11 & 1153236166 & Nebraska & 11 & 536.87 \\
\hline Wisconsin & 12 & 1146995763 & Oregon & 12 & 535.66 \\
\hline Minnesota & 13 & 1090999960 & Washington & 13 & 527.77 \\
\hline Indiana & 14 & 1079307208 & Colorado & 14 & 506.30 \\
\hline Tennessee & 15 & 901511069 & Iowa & 15 & 466.70 \\
\hline Washington & 16 & 824912180 & Kansas & 16 & 434.30 \\
\hline Oklahoma & 17 & 821025210 & Minnesota & 17 & 425.50 \\
\hline Alabama & 18 & 819689440 & Arkansas & 18 & 396.12 \\
\hline Kansas & 19 & 816920692 & Vermont & 19 & 390.49 \\
\hline Georgia & 20 & 793270890 & Wisconsin & 20 & 390.26 \\
\hline Louisiana & 21 & 777332649 & Michigan & 21 & 388.99 \\
\hline Nebraska & 22 & 739816299 & Ohio & 22 & 383.24 \\
\hline Arkansas & 23 & 734407732 & Florida & 23 & 377.21 \\
\hline North Carolina & 24 & 721348748 & Louisiana & 24 & 369.80 \\
\hline Mississippi & 25 & 719950715 & Illinois & 25 & 364.88 \\
\hline Kentucky & 26 & 656489291 & Texas & 26 & 361.70 \\
\hline Virginia & 27 & 617423756 & Mississippi & 27 & 358.18 \\
\hline Maryland & 28 & 562747966 & Maryland & 28 & 344.82 \\
\hline Florida & 29 & 553745638 & Tennessee & 29 & 344.48 \\
\hline South Carolina & 30 & 532884677 & Oklahoma & 30 & 342.66 \\
\hline Montana & 31 & 530633681 & Missouri & 31 & 340.07 \\
\hline Colorado & 32 & 524531880 & Maine & 32 & 336.07 \\
\hline Oregon & 33 & 511021747 & New York & 33 & 334.81 \\
\hline South Dakota & 34 & 486220790 & Indiana & 34 & 333.22 \\
\hline North Dakota & 35 & 482041916 & New Jersey & 35 & 330.47 \\
\hline West Virginia & 36 & 458388416 & Delaware & 36 & 310.13 \\
\hline Connecticut & 37 & 380738696 & Alabama & 37 & 309.78 \\
\hline Arizona & 38 & 345077459 & South Carolina & 38 & 306.43 \\
\hline Idaho & 39 & 331149924 & Massachusetts & 39 & 286.26 \\
\hline New Mexico & 40 & 291768941 & Georgia & 40 & 272.69 \\
\hline Utah & 41 & 289301781 & West Virginia & 41 & 265.11 \\
\hline Maine & 42 & 267853368 & Pennsylvania & 42 & 260.88 \\
\hline Wyoming & 43 & 202703636 & Virginia & 43 & 254.91 \\
\hline Rhode Island & 44 & 169393142 & Kentucky & 44 & 251.04 \\
\hline Vermont & 45 & 140577924 & New Hampshire & 45 & 247.76 \\
\hline Nevada & 46 & 136445094 & Rhode Island & 46 & 246.56 \\
\hline New Hampshire & 47 & 115212905 & Connecticut & 47 & 236.92 \\
\hline Delaware & 48 & 73812715 & North Carolina & 48 & 227.55 \\
\hline
\end{tabular}

Source: Office of Government Reports, Report 10, Vol. II.
Per Capita Allocation 1933-1939 (1930 population) 
TABLE 2

NEW DEAL EXPENDITURES, LOANS, AND INSURANCE

BY REGION, 1933 TO 1939

Absolute Allocation 1933-1939

Per Capita Allocation 1933-1939

\begin{tabular}{|c|c|c|c|c|c|}
\hline Region $^{a}$ & Rank & $\begin{array}{l}\text { Amount } \\
\text { in } \\
\text { Dollars }\end{array}$ & Region $^{a}$ & Rank & $\begin{array}{c}\text { Amount } \\
\text { in } \\
\text { Dollars }\end{array}$ \\
\hline Midwestern & 1 & 12920717580 & Mountain & 1 & 716.26 \\
\hline Western & 2 & 12495296644 & Pacific & 2 & 535.84 \\
\hline Northeastern & 3 & 10426587736 & Western & 3 & 504.86 \\
\hline Southeastern & 4 & 8849180988 & Great Plains & 4 & 424.22 \\
\hline Great Plains & 5 & 5452941738 & Midwestern & 5 & 380.44 \\
\hline Pacific & 6 & 4390742526 & Southeastern & 6 & 305.55 \\
\hline Mountain & 7 & 2651612396 & Northeastern & 7 & 300.78 \\
\hline
\end{tabular}

a Each region is made up of the following states:

Northeastern Region: Connecticut, Delaware, Maine, Massachusetts, New Hampshire, New Jersey, New York, Pennsylvania, Rhode Island, Vermont.

Southeastern Region: Alabama, Arkansas, Florida, Georgia, Kentucky, Louisiana, Maryland, Mississippi, North Carolina, South Carolina, Tennessee, Virginia, West Virginia.

Midwestern Region: Illinois, Indiana, Iowa, Michigan, Minnesota, Missouri, Ohio, Wisconsin.

Western Region: Arizona, California, Colorado, Idaho, Kansas, Montana, Nebraska, Nevada, New Mexico, North Dakota, Oklahoma, Oregon, South Dakota, Texas, Utah, Washington, Wyoming. Great Plains Region: Kansas, Nebraska, North Dakota, Oklahoma, South Dakota, Texas. Pacific Region: California, Oregon, Washington. Mountain States Region: Arizona, Colorado, Idaho, Montana, Nevada, New Mexico, Utah, Wyoming.

Source: Office of Government Reports, Report 10, Vol. II.

of farm activity. Some program loans or expenditures in specific states can be traced to large projects funded by a particular agency. For example, the per capita amount received by Montana from the Public Works Administration was twice that of any other state. This was due to the participation of the PWA in construction of the $\$ 100$ million Fort Peck Dam, which accounted for a high proportion of the large Montana allocation.

\section{HYPOTHESIS DEFINED}

In order to explain the wide differences in the per capita distribution of New Deal funds among states one must look for clues concerning the motivation of policy decisions in the vast outpouring of political rhetoric. While specific reasons may be cited for high per capita rankings for any given program in any given state, it is hypothesized that there was a general concept behind the pattern of expenditures in the various states. In the Fireside Chat, reviewing 
the achievements of the Seventy-third Congress in the late spring of 1934, Roosevelt outlined "three related steps" in "efforts toward the saving and safeguarding of our national life." 3 The first step was relief; the second, recovery; and the third, reform. Congress often looked at New Deal legislation as a two-stage program, with the first stage being relief and recovery and the second reform. These two subdivisions are used in the statistical analysis.

The federal government during the 1930's felt a need to improve the nation's assets as well as to direct expenditures toward relief, recovery, and reform. This was indicated in the same Fireside Chat when Roosevelt advocated a "plan to use land and water resources of this country to the end that the means of livelihood of our citizens may be more adequate to meet their daily needs."4

Seven independent variables have been selected and grouped into three major categories: national assets, relief and recovery, and reform. These variables are regressed on total per capita program activity from the years 1933 to 1939, in an effort to explain the disparity in per capita allocations to states.

\section{National Assets: Percent of Federal Land Owned in Each State, 1937}

Although federal administrators since the presidency of Theodore Roosevelt have had a fairly precise knowledge of the percent of federal land ownership in each state, the first exact data were published in 1937. The states ranged from a low of 0.10 percent in Iowa to a high of 83 percent in Nevada. Even though the time period is several years after the beginning of most New Deal spending programs, it is reasonable to assume that the relative mix of federal ownership did not change significantly from 1933 to 1937. Moreover, the data, in a disaggregate form, existed during the planning stages of New Deal programs. It is hypothesized that the federal government would invest more per capita in areas where it owned large amounts of land. One reason for this would be the upkeep and improvement of the natural resources over which the government had direct control. In addition it is desirable to minimize, within limits,

8 B. C. Zevin (ed.), Nothing to Fear: The Selected Addresses of Franklin Delano Roosevelt, 1932-1945 (Cambridge, Mass.: Houghton Mifflin Co., 1946), pp. 34-41.

4 Ibid., p. 39.

5 U.S. President, Message, "Federal Ownership of Real Estate and Its Bearing on State and Local Taxation," 76th Congress, 1st Session, House Misc. Doc. No. 111, Appendix A (Washington, D.C.: Government Printing Office, 1939). 
the transactions costs of Federal allocations. In general, states with larger percentages of Federal land would have established conduits through which monies could be channeled without the implementation of expensive bureaucratic machinery.

\section{National Assets: Per Capita Miles of State Highway Systems}

The per capita miles of highways in 1930 was calculated from total rural roads, municipal streets, and connecting highways in each state and divided by the 1930 population of the state. The 1930 population was selected because of the relatively accurate population figures for the census year. This variable is included because of the problem that large-area, low-population states have in financing highway systems and because of a national need to have an adequate interstate highway network. Such a system would facilitate the transportation of raw to finished goods from various geographical regions of the country. The nation's farmers tend to live in the more sparsely settled areas and have a real need for roads to deliver their product to areas of greater population.

Federal aid to state highway systems was distributed through several agencies and programs. Regular federal-aid road construction was usually funded by the Bureau of Public Roads. In addition, emergency road construction and grade-crossing projects were provided by the National Industrial Recovery Act of 1934 and by the Emergency Relief Appropriation Act of 1935. These federal funds were for highways, roads, grade-crossings, and streets.

\section{Relief and Recovery: Decline in Per Capita Real Personal In-} come, 1929-1933

The percent decline in real per capita personal income from 1929 to 1933 may be used to represent the administration's attempts to restore the purchasing power of the nation and return it to a pre1929 level. This is distinct from real per capita personal income which is used as a variable in the reform group. The time period of 1929-1933 corresponds with the percentage change over a cyclical period calculated by Abner Hurwitz and Carlyle P. Stallings for the National Bureau of Economic Research. ${ }^{6}$

6 Abner Hurwitz and Carlyle P. Stallings, "Inter-regional Differentials in Per Capita Real Income Changes," Studies in Income and Wealth, Vol. 21, National Bureau of Economic Research (Princeton: Princeton University Press, 1946), pp. 195-265. 


\section{Relief and Recovery: Unemployment in Each State, 1937}

Given the asserted goals of the New Deal, it would seem logical to assume that the states with the highest unemployment rates would receive substantial federal help. The year 1937 was used because that was the only year, other than the census years of 1930 and 1940 , in which a state-by-state unemployment enumeration was taken. In that year a special census of partial employment, unemployment and occupations for cities and states was released. The data used include the percentage of estimated population (not a percent of labor force) who registered in the census who were totally unemployed or emergency workers. The rates ranged from a high of 9.0 in Montana to a low of 3.4 in Iowa.

These percentages seem low due to the fact that the unemployment totals were divided by total population rather than by total labor force, as is the common practice today. A defensible statistical definition of "labor force" was not developed and generally accepted until the census of 1940. The census of 1930 used the term "gainful workers," which is less rigorously defined than "labor force." The lack of adequate unemployment data led to the special 1937 Census of Unemployment, whose figures are used here. While the data presented are questionable by modern standards, they offer the best state-by-state analysis of unemployment during the 1930's. The special 1937 census of unemployment was also used by New Deal planners.

\section{Reform: Level of Personal Income, 1933}

If the Roosevelt administration were to achieve its goal as a reformer of national inequities, one might expect that it would expend a greater portion of its funds in states with the lowest real per capita personal income. The year 1933 was selected to represent the trough of the depression.

\section{Reform: Number of Tenant Farms, 1930}

Even though Congress often balked at funding the programs of the Roosevelt administration, it approved several programs aimed at helping farmers obtain the land they worked. It is hypothesized that the New Deal planners wanted to aid in reforming the inequities of the rural sector and that the greater per capita funds would flow to states with a higher percent of tenant farms. 
7. Reform: Number of Blacks, 1930

One might hypothesize that the percent of state population which was black might have been a factor in influencing the amount of allocations of New Deal agencies to the various states. The economic plight of the blacks was well known to New Deal planners. As a reform measure one would assume greater per capita effort to states with higher percents of blacks to total state population.

\section{ANALYSIS OF REGRESSION EQUATIONS}

The data given above were selected because the precise data, or a near-equivalent, would have been at the disposal of New Deal planners. We may then use the variables as follows:

National Assets:

$\mathrm{X}_{1}$ : The percent of federal land owned in each state, 1948.

$\mathrm{X}_{2}$ : Per capita highway miles, 1930.

Relief and Recovery:

$\mathrm{X}_{3}$ : Percent decline in real per capita personal income, 1929-33.

$\mathrm{X}_{4}$ : Percent unemployment 1937.

Reform:

$\mathrm{X}_{5}$ : Real per capita personal income, 1933.

$\mathrm{X}_{6}$ : Percent tenant farms, 1933.

$\mathrm{X}_{7}$ : Percent black, 1930.

The selection of variables to stand as proxies for governmental policy statements is tenuous at best. One complicating factor is the possibility of multicollinearity. This problem became especially acute in the selection of variables to stand proxie for the goal of reform. Several variables were chosen, but rejected, because of the problem of collinearity. One of the most logical to use is the illiteracy rate which had a simple correlation coefficient with percent black of .81 and with a percent of tenant farms of .72 .

Another variable which would be logical to add to the reform group would be the distribution of income. This variable could not be added to the reform group because of insufficient data. While several excellent income distribution studies of the New Deal period have been undertaken, no data have been available on a state-bystate basis. The income studies taken during the 1930's were done with a stratified sample which did not cover every state, and this 
information was not included in the census until 1950. State-by-state breakdowns of income distribution are available for 1949, but an analysis based on backward extrapolation of these data would certainly seem invalid. Since World War II there have been major shifts in the distribution of income within states.

If the New Deal was successful in all the goals set by Franklin Roosevelt, to the extent that the afore-mentioned variables measure the effects of this policy, there should be a significant relationship between each of the independent variables, $\left(X_{1} X_{2} \ldots X_{7}\right)$ and the per capita allocations (the dependent variable). All signs on the $X_{1}$ are hypothesized to be positive with the exception of $\mathrm{X}_{5}$ (the lower the per capita personal income, the higher the per capita expenditures). If only parts were successful, the independent variable within any one of the three groups should be statistically significant while the variables in any of the others would be insignificant. The regression results are given in Table 3 with an explanation of each of the independent variables following.

\section{EXPLANATION OF REGRESSIONS}

Using per capita expenditures as the dependent variable, the significance of the four independent variables $X_{1}$ through $X_{4}$ would indicate that the Roosevelt administration allocated funds from expenditure programs on a per capita basis to states where there was a need to aid in the development of national assets and to assist in relief and recovery. However, per capita expenditure funds were not allocated in relation to reform. The percent of explained variation in the dependent variable, per capita expenditures, by the independent variables, or the $R^{2}$, is .84 .

When regressing the selected independent variables $X_{1}$ through $\mathrm{X}_{7}$ on per capita loans, we are confident at the .10 level that the independent variables $X_{1}$ through $X_{3}$ are significantly related to per capita loans. This indicates that $\mathrm{X}_{4}$, or percent unemployment, did not exert a statistically significant influence on the direction of flow of New Deal lending programs. This result is not surprising given the nature of programs aimed at aiding unemployment, such as Works Progress Administration, Public Works Administration, Civil Works Administration, and Federal Emergency Relief Administration, which were all grant and not loan programs. Given the selected

7 The residuals for each regression were very random with no extreme values. 
TABLE 3

REGRESSION RESULTS

\begin{tabular}{|c|c|c|c|c|c|c|c|c|c|}
\hline & & $\mathrm{X}_{1}$ & $\mathrm{X}_{2}$ & $\mathrm{X}_{3}$ & $\mathrm{X}_{4}$ & $\mathrm{X}_{5}$ & $\mathrm{X}_{6}$ & $\mathrm{X}_{7}$ & \\
\hline 1. & Expenditures & $\begin{array}{l}4.04^{\mathrm{a}} \\
(.78)\end{array}$ & $\begin{array}{c}9.99^{\mathrm{a}} \\
(1.63)\end{array}$ & $\begin{array}{l}5.12^{\mathrm{a}} \\
(2.27)\end{array}$ & $\begin{array}{l}16.45^{a} \\
(9.90)\end{array}$ & $\begin{array}{l}.07 \\
(.08)\end{array}$ & $\begin{array}{l}1.31 \\
(1.22)\end{array}$ & $\begin{array}{l}-1.40 \\
(1.56)\end{array}$ & $\begin{array}{l}\text { Alpha }=-151.4 \\
\mathrm{R}=.84 \\
\mathrm{DW}=2.09\end{array}$ \\
\hline 2. & Loans & $\begin{array}{l}1.09^{\mathrm{a}} \\
(.47)\end{array}$ & $\begin{array}{l}1.41^{\mathrm{a}} \\
(.97)\end{array}$ & $\begin{array}{r}3.45 \mathrm{a} \\
(1.35)\end{array}$ & $\begin{array}{c}-7.24 \\
(5.89)\end{array}$ & $\begin{array}{l}.01 \\
(.05)\end{array}$ & $\begin{array}{l}1.06 \\
(.72)\end{array}$ & $\begin{array}{r}-1.53 \\
(.93)\end{array}$ & $\begin{array}{l}\text { Alpha }=30.4 \\
R=.59 \\
\text { DW }=1.92\end{array}$ \\
\hline 3. & $\begin{array}{l}\text { Expenditures } \\
\text { and Loans }\end{array}$ & $\begin{array}{l}5.13^{\mathrm{a}} \\
(1.10)\end{array}$ & $\begin{array}{l}11.33^{a} \\
(2.29)\end{array}$ & $\begin{array}{c}8.47 \mathrm{a} \\
(3.19)\end{array}$ & $\begin{array}{c}8.63 \\
(13.93)\end{array}$ & $\begin{array}{l}.07 \\
(.11)\end{array}$ & $\begin{array}{c}2.33 \\
(1.71)\end{array}$ & $\begin{array}{c}-3.05 \\
(2.19)\end{array}$ & $\begin{array}{l}\text { Alpha }=-112.4 \\
\mathrm{R}=.81 \\
\mathrm{DW}=1.89\end{array}$ \\
\hline 4. & $\begin{array}{l}\text { Expenditures } \\
\text { Loans and } \\
\text { Insurance }\end{array}$ & $\begin{array}{l}5.71^{\mathrm{a}} \\
(1.12)\end{array}$ & $\begin{array}{c}11.05^{a} \\
(2.31)\end{array}$ & $\begin{array}{c}8.51^{\mathrm{a}} \\
(3.23)\end{array}$ & $\begin{array}{c}7.41 \\
(14.09)\end{array}$ & $\begin{array}{l}.12 \\
(.11)\end{array}$ & $\begin{array}{c}2.17 \\
(1.34)\end{array}$ & $\begin{array}{c}-2.48 \\
(2.22)\end{array}$ & $\begin{array}{l}\text { Alpha }=-119.4 \\
\mathrm{R}=.81 \\
\mathrm{DW}=1.89\end{array}$ \\
\hline
\end{tabular}

a Significant at the .10 level. Standard error of the coefficient listed below the coefficient. Alpha is the intercept term. Source: See text. 
TABLE 4

CORRELATION COEFFICIENTS OF INDEPENDENT VARIABLES

\begin{tabular}{rrrrrrrr}
\hline & $\mathrm{X}_{1}$ & \multicolumn{1}{c}{$\mathrm{X}_{2}$} & \multicolumn{1}{c}{$\mathrm{X}_{3}$} & \multicolumn{1}{c}{$\mathrm{X}_{4}$} & \multicolumn{1}{c}{$\mathrm{X}_{5}$} & \multicolumn{1}{c}{$\mathrm{X}_{6}$} & \multicolumn{1}{c}{$\mathrm{X}_{7}$} \\
\hline $\mathrm{X}_{1}$ & 1.000 & .561 & .300 & .395 & .463 & -.309 & -.314 \\
$\mathrm{X}_{2}$ & & 1.000 & -.044 & -.182 & -.072 & -.162 & -.084 \\
$\mathrm{X}_{3}$ & & & 1.000 & .175 & -.287 & .163 & -.301 \\
$\mathrm{X}_{4}$ & & & & 1.000 & .118 & -.142 & -.172 \\
$\mathrm{X}_{5}$ & & & & & 1.000 & -.687 & -.481 \\
$\mathrm{X}_{6}$ & & & & & & 1.000 & .732 \\
$\mathrm{X}_{7}$ & & & & & & & 1.000 \\
\hline
\end{tabular}

Source: See text.

variables, New Deal loans flowed in greater per capita amounts to states to aid in the development of national assets and higher amounts of decline in per capita real personal income than for unemployment relief or reform.

Given the variables representing Roosevelt's three stated goals, the analysis leads to the conclusion that per capita loans flowed in relation to national assets, for relief and recovery in relation to percent decline in real per capita income but not unemployment, and again, as in the case of per capita expenditures, not for reform. The relatively low $R^{2}$ in the case of per capita loans is probably due to the fact that the largest lending programs were to aid financial institutions (Reconstruction Finance Corporation) or the agricultural sector (Farm Credit Administration, Commodity Credit Corporation, Farm Security Administration), and these two sectors are not explicitly represented in the independent variables.

The results of regressions on per capita loans and expenditures and per capita expenditures, loans, and insurance were similar to those of per capita loans, even though the percent of explained variation $\left(R^{2}=.81\right)$ is higher. The same independent variables are significant $\left(X_{1}\right.$ through $\left.X_{3}\right)$, filling the group selected to represent national assets and a relief and recovery variable (percent decline in real per capita personal income) while unemployment and the reform variables add little to the explained variation in the respective dependent variable.

\section{GENERAL OBSERVATIONS}

A distinction should be made between the two independent variables, $\mathrm{X}_{3}$ (percent decline in real per capita income) and $\mathrm{X}_{5}$ (per capita real personal income). The fact that there is a significant 
relationship between each case and the percent decline in real per capita income, and in no case a significant relationship with per capita personal income, seems to provide an insight into New Deal thinking. The simple correlation coefficient between $X_{3}$ and $X_{5}$ is -.28. Apparently, the Roosevelt administration was more concerned with returning purchasing power, through increasing real per capita income, to a pre-1929 level than it was in equalizing real per capita income between states. ${ }^{8}$ Per capita funds flowed in all categories of New Deal programs in greater amounts to those states where the real per capita income drop was the greatest, but not to the states with a relatively low level of real per capita personal income. Perhaps the New Deal planners were reacting to the concepts that have been pointed out in recent models of discontent. People seem to adjust to a given level of income irrespective of size, and reductions in income are met with unrest and discontent. It would be politically advantageous to allocate funds to restore income to groups whose incomes have dropped. Once the incomes have been restored, the marginal dollar spent on that group would mean less than a dollar allocated to groups whose incomes were still below their previous income level. ${ }^{\circ}$

As in the case of analyzing $\mathrm{X}_{7}$, the percent of state population that is black, the sign of the coefficient $X_{5}$, real per capita income, is the opposite of what would be expected if the Roosevelt administration was trying to reform per capita income inequities among states. Even though non-significant, the sign of the coefficient of $X_{5}$ was positive in each regression case. One would expect that, if reform was a goal of the New Deal and greater income equality was a reform goal, greater per capita expenditures would flow to states with the lowest real per capita income and, hence, a negative coefficient would be the result.

Given the selected variables to fill the definitions of national assets, relief and recovery, and reform, the actual per capita direction of New Deal funds fulfilled the goal of improving national assets and contributed toward the return of the economy to a pre-1929 level. Unemployment was attacked through expenditure, but not through lending programs, and reform was left wanting in all categories of programs. Given these results, one may posit that Roose-

8 This same result was found by L. J. Arrington, "Western Agriculture and the New Deal," Agricultural History, XLIV (October 1970) 337-353.

9 This important concept was pointed out by an anonymous referee. 
velt took two of the steps outlined in his June, 1934 Fireside Chat: namely, improving America's national assets and relief and recovery, but failed to achieve the quantifiable elements in the goal of reform. ${ }^{10}$

The logic of political attitudes, if they could be measured accurately, are difficult to untangle. Would the administration direct funds to areas where Roosevelt's popularity was relatively low in an attempt to "buy" votes, or would it hold back funds to financially "punish" a state for not supporting the administration?"11

Several variables which could be expected to influence the flow of per capita New Deal funds to states are nearly impossible to quantify and, thus, were not included as independent variables in the regression analysis. An important one on both the federal and state levels is the willingness of state and local units to set up the machinery for the disbursement of federal funds. The vigor with which state officials lobbied for programs which would affect their particular area would seem to have a pronounced effect on the flow of funds.

A review of the literature of federal spending in states during the 1930's makes one aware of the difference in attitudes of state and local officials toward federal programs in their states. Many highranking state officials believed that federal agencies entered into activities which better belonged under state jurisdiction. This seems most true in the southern and New England states. One example of the extent to which state officials would go in protesting federal intervention was the case of Governor Francis P. Murphy of New Hampshire. After a devastating hurricane struck New England in September of 1938, the Disaster Loan Corporation, the Works Progress Administration, and the Public Works Administration imple-

10 The wife of the President, Mrs. Roosevelt, stated in a speech in February of 1939 that New Deal programs "helped but they did not solve the fundamental problems." See Henry Wallace, The Christian Bases of World Order (New York: Abingdon Cokesbury Press, 1943), p. 17. Also the failure of general reform has been noted by several New Deal historians. (Douglass C. North, Growth and Welfare in the American Past, 1966, pp. 174-180, and Paul K. Conkin The New Deal, 1967, pp. 172-73.

11 Gavin Wright has found some interesting political measures which seem to be correlated with New Deal spending (forthcoming in Review of Economics and Statistics). He uses electoral votes per capita, the variability of a state's voting pattern (standard deviation), and the absolute difference between .500 and a "predicted" level of Democratic share in 1932. There is a high degree of multicollinearity between several of our independent variables especially electoral votes per capita, percent Federal land owned, and per capita highway miles. 
mented an \$11 million flood-control plan. Governor Murphy opposed the federal intervention and attempted to implement court appeals to prevent federal flood-control work in New Hampshire. This general attitude does not seem as apparent in western states where the highest per capita loans and expenditures were directed.

Even when a given program was established in each state, as in the case of Social Security, there was a wide difference in the implementation of given programs. One measure which gives an indication of this is the "waiting line" for Social Security benefits. This "waiting line" is the number of people per 100 on Social Security that applied for benefits and were waiting for their applications to be processed. The number in each state varied widely. Utah, as of June, 1938, had a "waiting line" number of 0.9, while Georgia had 204.2. Not all applications would be approved, but the amount of funds disbursed in the state would be lower where many applications were in process. Generally, the southern states had the highest "waiting line" and numbers in the western states were the lowest.

In general, the western states seemed most willing to extend an open hand to Washington, while New England and southern states were most antagonistic to federal programs. An exception to this in the southern states was the acceptance of federal agricultural programs, such as the Commodity Credit Corporation, which dealt, among other things, with cotton and tobacco. While no quantifiable statistic is available which would indicate "willingness to accept federal programs," this concept seems to have played an important role in the flow of per capita New Deal funds to given states.

\section{SUMMARY}

The results of the analysis suggest that, given the independent variables selected, New Deal agencies failed to expend in a pattern that would effect reform, but did expend in a pattern that would contribute to relief and recovery and at the same time improve the utilization of natural resources. The statistical analysis also yields some interesting insights into the New Deal philosophy. There is a significant positive relationship between New Deal activity and the percent decline in real per capita personal income, but an insignificant relationship between the level of real per capita income and New Deal spending. This would seem to indicate that the Roosevelt administration was content with the modest goal of seeking to re- 
turn incomes to a pre-1929 level rather than striving to equalize per capita income between states and regions.

The investigation of New Deal programs leads, as one would expect, to many additional questions. What were the political influences behind the pattern of state allocations? Was Roosevelt attempting to buy votes in the west and shorting the south because it was strongly Democratic? How did the fixed and variable costs of implementing the various programs in different states affect the pattern of allocations? What was the economic impact of given programs in given states and regions? What were the year-to-year changes in New Deal effort for the years 1933-1939?

The data presented in this study provide a basis for further study of specific program activity in all or any grouping of states and the expenditures of all or any group of programs in any one state.

Don C. Reading, Idaho State University

APPENDIX

\section{BIBLIOGRAPHY}

\section{Books}

Chandler, Lester V. America's Greatest Depression, 1929-1941. New York: Harper and Row, 1970.

Conkin, Paul K. The New Deal. New York: Thomas Y. Crowell Co., 1967. Hurwitz, Abner, and Stallings, C.P., Studies in Income and Wealth. Princeton, N. J.: Princeton University Press, 1946.

Leuchtenburg, William E. Franklin D. Roosevelt and the New Deal. New York: Harper Torch Books, 1963.

North, Douglass, C. Growth and Welfare in the American Past. Englewood Cliffs, N.J.: Prentice-Hall, Inc., 1966.

Schlesinger, Arthur M. The Age of Roosevelt. 3 Vol. Boston, Mass.: Houghton Mifflin Co., 1957-1960.

Wallace, Henry A. Christian Bases of World Order. New York: AbingdonCokesbury Press, 1943.

Zevin, B. C. (ed.). Nothing to Fear: The Selected Addresses of Franklin Delano Roosevelt, 1932-1945. Cambridge, Mass.: Riverside Press, 1946.

\section{Articles in Periodicals}

Arrington, Leonard J. "The New Deal in the West: A Preliminary Statistical Inquiry." Pacific Historical Review, XXXVIII (August 1969), 311316.

Arrington, Leonard J. "Western Agriculture and the New Deal." Agricultural History, XLIV (October, 1970), 337-353. 


\section{Public Documents}

Census of Partial Employment, Unemployment and Occupations, Final Report on Total and Partial Unemployment: United States Summary, Washington, D.C., 1938.

Office of Government Reports, Statistical Section, Federal Loans and Expenditures, Vol. II, Washington, D.C. 1940.

U.S. President, Message, Federal Ownership of Real Estate and Its Bearing on State and Local Taxation (76th Congress, 1st Session, House Misc. Doc. No. III, Appendix A, Washington, D.C.: Government Printing Office, 1939. I.

U.S. Dept of Commerce, Personal Income by States, Supplement to the Survey of Current Business (Washington, D.C.: U.S. Government Printing Office, 1956), p. 140. 
Appendix Table I

NEW DEAL EXPENDITURES BY STATES

1933-1939

\begin{tabular}{|c|c|c|}
\hline State & Rank & $\begin{array}{c}\text { Amount in } \\
\text { Dollars }\end{array}$ \\
\hline New York & 1 & 2581360614 \\
\hline Pennsylvania & 2 & 1819998951. \\
\hline Illinois & 3 & 1520690490. \\
\hline California & 4 & 1511706770. \\
\hline Ohio & 5 & 1447727438 . \\
\hline Texas & 6 & 1195966708. \\
\hline Massachusetts & 7 & 921496189. \\
\hline Michigan & 8 & 916990154. \\
\hline Missouri & 9 & 862880012 . \\
\hline New Jersey & 10 & 714904976. \\
\hline Minnesota & 11 & 697604861. \\
\hline Wisconsin & 12 & 688037358. \\
\hline Indiana & 13 & 667863294. \\
\hline Tennessee & 14 & 587353896. \\
\hline Washington & 15 & 582679256. \\
\hline Oklahoma & 16 & 575634629. \\
\hline Iowa & 17 & 572534447. \\
\hline Alabama & 18 & 551982381. \\
\hline Kansas & 19 & 528454144 . \\
\hline Georgia & 20 & 495780782 . \\
\hline Arkansas & 21 & 475420579 . \\
\hline Kentucky & 22 & 471740714. \\
\hline North Carolina & 23 & 467008102 . \\
\hline Louisiana & 24 & 465361889. \\
\hline Mississippi & 25 & 457713463. \\
\hline Virginia & 26 & 423795812 \\
\hline Nebraska & 27 & 400273394. \\
\hline Montana & 28 & 381382693. \\
\hline Colorado & 29 & 375101905 . \\
\hline Florida & 30 & 363572887. \\
\hline West Virginia & 31 & 350160231. \\
\hline South Carolina & 32 & 344947572 . \\
\hline Oregon & 33 & 338809347. \\
\hline South Dakota & 34 & 308967220 . \\
\hline Maryland & 35 & 302702368. \\
\hline North Dakota & 36 & 293323694 . \\
\hline Arizona & 37 & 261368351. \\
\hline Connecticut & 38 & 252099663. \\
\hline New Mexico & 39 & 223301907. \\
\hline Idaho & 40 & 209057598. \\
\hline Utah & 41 & 173886682. \\
\hline Maine & 42 & 157636941. \\
\hline Wyoming & 43 & 141185431. \\
\hline Rhode Island & 44 & 114788954. \\
\hline Nevada & 45 & 102881055 \\
\hline Vermont & 46 & 90764059. \\
\hline New Hampshire & 47 & 89508795. \\
\hline Delaware & 48 & 57865708. \\
\hline
\end{tabular}

Source: Office of Government Reports, Report 10, Vol. II. 
Appendix Table II

NEW DEAL LOANS BY STATES

1933-1939

\begin{tabular}{|c|c|c|}
\hline State & Rank & $\begin{array}{c}\text { Amount in } \\
\text { Dollars }\end{array}$ \\
\hline New York & 1 & 1320966962 \\
\hline Illinois & 2 & 1108692790 . \\
\hline California & 3 & 1072149629. \\
\hline Ohio & 4 & 950210837. \\
\hline Texas & 5 & 805735655 . \\
\hline Michigan & 6 & 788916729 . \\
\hline Iowa & 7 & 558649362. \\
\hline Pennsylvania & 8 & 540025723. \\
\hline New Jersey & 9 & 460355548. \\
\hline Wisconsin & 10 & 421191640 . \\
\hline Minnesota & 11 & 352420919 . \\
\hline Indiana & 12 & 336850461 . \\
\hline Nebraska & 13 & 326600036. \\
\hline Missouri & 14 & 303588957. \\
\hline Louisiana & 15 & 290761205. \\
\hline Tennessee & 16 & 274994595. \\
\hline Kansas & 17 & 262134455. \\
\hline Georgia & 18 & 258198500. \\
\hline Massachusetts & 19 & 246187391. \\
\hline Alabama & 20 & 245376802. \\
\hline Arkansas & 21 & 245162281. \\
\hline Mississippi & 22 & 244304626. \\
\hline North Carolina & 23 & 228068077. \\
\hline Maryland & 24 & 215077024. \\
\hline Oklahoma & 25 & 213505566. \\
\hline North Dakota & 26 & 185055710 . \\
\hline Washington & 27 & 184791618. \\
\hline South Carolina & 28 & 173415790 . \\
\hline South Dakota & 29 & 172206250 . \\
\hline Kentucky & 30 & 157543584 . \\
\hline Oregon & 31 & 149639324. \\
\hline Virginia & 32 & 145563452. \\
\hline Montana & 33 & 141835952. \\
\hline Florida & 34 & 131506445. \\
\hline Colorado & 35 & 130686722. \\
\hline Idaho & 36 & 111804931. \\
\hline Maine & 37 & 103899219. \\
\hline Utah & 38 & 97505718 \\
\hline Connecticut & 39 & 96598582 . \\
\hline West Virginia & 40 & 90365263. \\
\hline Arizona & 41 & 67866224. \\
\hline New Mexico & 42 & 61907530. \\
\hline Wyoming & 43 & 52878973. \\
\hline Vermont & 44 & 44735388. \\
\hline Rhode Island & 45 & 41074323. \\
\hline Nevada & 46 & 28472659. \\
\hline New Hampshire & 47 & 19371630. \\
\hline Delaware & 48 & 9373501. \\
\hline
\end{tabular}

Source: Office of Government Reports, Report 10, Vol. II. 
APPENDIX TABLE III

NEW DEAL INSURANCE PROGRAMS BY STATES 1933-1939

\begin{tabular}{|c|c|c|}
\hline State & Rank & $\begin{array}{l}\text { Amount in } \\
\text { Dollars }\end{array}$ \\
\hline California & 1 & 470952197. \\
\hline New York & 2 & 312304593. \\
\hline Michigan & 3 & 177589022 . \\
\hline New Jersey & 4 & 160179808. \\
\hline Illinois & 5 & 155032728. \\
\hline Pennsylvania & 6 & 152573958. \\
\hline Ohio & 7 & 150181544 . \\
\hline Texas & 8 & 105214465. \\
\hline Indiana & 9 & 74593452 . \\
\hline Missouri & 10 & 67677787. \\
\hline Florida & 11 & 58666306. \\
\hline Washington & 12 & 57441306. \\
\hline Massachusetts & 13 & 48644291. \\
\hline Virginia & 14 & 48054492 . \\
\hline Maryland & 15 & 44968574 . \\
\hline Minnesota & 16 & 40974179. \\
\hline Georgia & 17 & 39291608. \\
\hline Tennessee & 18 & 39162578. \\
\hline Wisconsin & 19 & 37766764 . \\
\hline Connecticut & 20 & 32040451 . \\
\hline Oklahoma & 21 & 31885015 . \\
\hline Kentucky & 22 & 27204993. \\
\hline Kansas & 23 & 26332093. \\
\hline North Carolina & 24 & 26272569 . \\
\hline Oregon & 25 & 22573076 . \\
\hline Alabama & 26 & 22330257. \\
\hline Iowa & 27 & 22052356 . \\
\hline Louisiana & 28 & 21209555. \\
\hline Colorado & 29 & 18743253. \\
\hline Mississippi & 30 & 17932626. \\
\hline Utah & 31 & 17909381. \\
\hline West Virginia & 32 & 17862922. \\
\hline Arizona & 33 & 15842884. \\
\hline South Carolina & 34 & 14521315 . \\
\hline Arkansas & 35 & 13824872 . \\
\hline Rhode Island & 36 & 13529865. \\
\hline Nebraska & 37 & 12942869. \\
\hline Idaho & 38 & 10287395 . \\
\hline Wyoming & 39 & 8639232. \\
\hline Montana & 40 & 7415036. \\
\hline Delaware & 41 & 6573506. \\
\hline New Mexico & 42 & 6559504 . \\
\hline New Hampshire & 43 & 6332480 . \\
\hline Maine & 44 & 6317208. \\
\hline Nevada & 45 & 5091380. \\
\hline Vermont & 46 & 5078477. \\
\hline South Dakota & 47 & 5047320 . \\
\hline North Dakota & 48 & 3662512 . \\
\hline
\end{tabular}

Source: Office of Government Reports, Report 10, Vol. II. 